Editorial

\title{
Practices to Conserve Pollinators and Natural Enemies in Agro-Ecosystems
}

\author{
Filitsa Karamaouna ${ }^{1, *}$, Josep A. Jaques ${ }^{2, *}$ id and Vaya Kati ${ }^{1, *}$ \\ 1 Scientific Directorate of Pesticides Assessment and Phytopharmacy, Benaki Phytopathological Institute, \\ 7 Ekalis str., 14561 Kifissia, Greece \\ 2 Departament de Ciències Agràries i del Medi Natural, Universitat Jaume I, Campus del Riu Sec, Av. de Vicent \\ Sos Baynat, s/n, 12071 Castelló de la Plana, Spain \\ * Correspondence: f.karamaouna@bpi.gr (F.K.); josep.jaques@camn.uji.es (J.A.J.); v.kati@bpi.gr (V.K.)
}

check for updates

Citation: Karamaouna, F.; Jaques, J.A.; Kati, V. Practices to Conserve Pollinators and Natural Enemies in Agro-Ecosystems. Insects 2021, 12, 31. https://doi.org/10.3390/insects1 2010031

Received: 29 December 2020 Accepted: 2 January 2021 Published: 5 January 2021

Publisher's Note: MDPI stays neutral with regard to jurisdictional clai$\mathrm{ms}$ in published maps and institutional affiliations.

Copyright: (C) 2021 by the authors. Licensee MDPI, Basel, Switzerland. This article is an open access article distributed under the terms and conditions of the Creative Commons Attribution (CC BY) license (https:// creativecommons.org/licenses/by/ $4.0 /)$.

\section{Introduction}

Intensive agriculture has put great pressure on populations of beneficial arthropods such as natural enemies and pollinators, especially through adverse effects of pesticide use and the impact on resources in the agricultural landscape, i.e., the reduction of suitable habitats for foraging and nesting sites. The main associated consequences include the decline of biological diversity and delivery of the ecosystem services of biological control and pollination; as a subsequent result, the sustainability of agro-ecosystems is undermined [1-9].

Sustainable agronomic practices such as management of field margins and mid-field strips with selected flower plants, cover crops, banker plants, uncultivated areas (set aside), headlands, and hedges can create suitable habitats that provide food and shelter to pollinators and to natural enemies of insect pests in disturbed agro-ecosystems [9-21].

The successful establishment of such habitats requires a good understanding of the food-web theory with respect to functional plant-arthropod diversity, regulation of herbivore populations by manipulation of bottom-up and top-down effects, and crop pollination. Multiple criteria should be considered regarding the selection of plant species for the semi-natural habitats, such as their soil/climatic requirements, growth habits, flowering periods, nectar and pollen production, and flower structure; their potential to become weeds and threaten crop productivity and native flora biodiversity; and finally the tri-trophic interactions between the plants, pests, and target beneficials.

The spread and possible dominance of a single or only a few plant species would have a direct impact on the desired insect communities in respect to functional biodiversity. Indeed, a narrow plant species selection could support conservation of a certain pollinator group or species in the target area [12,13,22]. In the study by Carvell et al. (2007) [22] a legume-based pollen and nectar flower mix targeted to enhance bumble bee populations in the U.K. could quickly provide a highly attractive forage resource for bumble bees, including rare long-tongued species, whereas a diverse mixture of native wild flowers could attract more of the shorter-tongued Bombus spp. and provide greater continuity of forage resources, especially early in the season. In the case of natural enemies, it is widely recognized that increasing biodiversity per se is no guarantee of pest suppression [23]. In general, the key to effective biological control may be tactics that enhance the relative abundance of the most effective natural enemies within the community of natural enemies [24]. Communities are usually characterized as having one or a few species which are relatively abundant (numerically dominant), while the majority of the members of the assemblage are relatively scarce. Moreno et al. (2010) [25] suggested that the success of management strategies by conservation biological control may be dependent on the identification of both highly abundant and scarce natural enemies to determine which assemblage is likely to work best. Nevertheless, the established plant species could possibly attract herbivorous pest species for the crop, higher-order predators/hyperparasitoids, or plant diseases [26]. 
Specificity on flower species as well as interactions between pollinator species at food searching, especially between managed honey bees and wild bees, are also aspects to be looked at in their habitat creation. Specificity on one or a few particular plant species is an attribute recognized in many insect pollinators when visiting a given foraging bout because floral consistency reduces handling time [27-30]. However, the fidelity between the pollinator species and plant species from one year to the next can be affected by many parameters such as the degree of specialization of the pollinator species (oligolectic or polylectic, some species being apparently specialist in one year but generalist in another even though the potential plant species pool remains the same) [31-33], and the patch area and flower density of the available flowering plant assemblages [34,35]. On the other hand, Shavit et al. (2009) [36] provided evidence that solitary bees did not shift to forage on other flowering plants and did not change their temporal activity pattern as a response to increased foraging by honey bees.

The benefit of these agronomic practices on the attraction of natural enemies and pollinating insects has been recognized within the flower strip or cover crop in several annual (e.g., cucumber, tomato, watermelon) [37-39] or perennial crops (e.g., apple, citrus, olive) [40-42]. In fact, the beneficial effect of diversifying fields with nectar-producing floral vegetation on parasitism rates and biological control of insect pests has been supported for several groundcover species and crops by many researchers [14,20,21,43,44]. However, in the case of pollinators, the effect of flower margins on pollination services in terms of yield and fruit quality at farm scale is not yet well established [21]. The value of wild bees in crop pollination was satisfactory in several agro-ecosystems with high populations of wild bees [45-48], while pollination was insufficient to achieve an acceptable crop yield without managed honey bees in other agro-ecosystems where the abundance or diversity of wild bees was low $[45,46,49]$. Greater richness of wild bees in agro-ecosystems increases the possibilities for the coexistence of the most effective pollinator species which act complementary to each other during the day or season, alongside extreme climatic conditions and disturbance levels, and would provide sustainability in the agro-ecosystems [30,50-52].

This Special Issue aims to focus on good agronomic practices/mitigation measures to sustain and enhance pollinators and natural enemies in terms of plant-arthropod interactions, functional biodiversity, and ecosystem services in cultivated areas.

Funding: This research received no external funding.

Conflicts of Interest: The authors declare no conflict of interest.

\section{References}

1. Matson, P.A.; Parton, W.J.; Power, A.G.; Swift, M.J. Agricultural intensification and ecosystem properties. Science 1997, 277, 504-509. [CrossRef]

2. Stoate, C.; Boatman, N.D.; Borralho, R.J.; Rio Carvalho, C.; de Snoo, G.R.; Eden, P. Ecological impacts of arable intensification in Europe. J. Environ. Mana. 2001, 63, 337-365. [CrossRef]

3. Robinson, R.A.; Sutherland, W.J. Post-war changes in arable farming and biodiversity in Great Britain. J. Appl. Ecol. 2002, 39, 157-176. [CrossRef]

4. Tillman, D.; Gassman, K.G.; Matson, P.A.; Naylor, R.; Polasky, S. Agricultural sustainability and intensive production practices. Nature 2002, 418, 671-677. [CrossRef]

5. Carvell, C.; Roy, D.B.; Smart, S.M.; Pywell, R.F.; Preston, C.D.; Goulson, D. Declines in forage availability for bumblebees at a national scale. Biol. Cons. 2006, 132, 481-489. [CrossRef]

6. Klein, A.-M.; Vaissiere, B.E.; Cane, J.H.; Steffan-Dewenter, I.; Cunningham, S.A.; Kremen, C.; Tscharntke, T. Importance of pollinators in changing landscapes for world crops. Proc. R. Soc. Lond. [Biol.] 2007, 274, 303-313. [CrossRef]

7. Wade, M.R.; Gurr, G.M.; Wratten, S.D. Ecological restoration of farmland: Progress and prospects. Phil. Trans. R. Soc. B 2008, 363, 831-847. [CrossRef]

8. Potts, S.G.; Biesmeijer, J.C.; Kremen, C.; Neumann, P.; Schweiger, O. Global pollinator declines: Trends, impacts and drivers. Trends Ecol. Evol. 2010, 25, 345-353. [CrossRef]

9. Bretagnolle, V.; Gaba, S. Weeds for bees? A review. Agron. Sustain. 2015, 35, 891-909. [CrossRef]

10. Carvell, C.; Meek, W.R.; Pywell, R.F.; Nowakowski, M. The response of foraging bumblebees to successional change in newly created arable field margins. Biol. Cons. 2004, 118, 327-339. [CrossRef] 
11. Gurr, G.M.; Wratten, S.D.; Altieri, M.A. Ecological Engineering for Pest Management: Advances in Habitat Manipulation for Arthropods; CSIRO publishing: Collingwood, VI, Australia, 2004.

12. Pywell, R.F.; James, K.L.; Herbert, I.; Meek, W.R.; Carvell, C.; Bell, D.; Sparks, T.H. Determinants of overwintering habitat quality for beetles and spiders on arable farmland. Biol. Conserv. 2005, 123, 79-90. [CrossRef]

13. Pywell, R.F.; Warman, E.A.; Carvel, C.; Sparks, T.H.; Dicks, L.V.; Bennet, D.; Wright, A.; Chritchley, C.N.R.; Sherwood, A. Providing foraging resources for bumblebees in intensively farmed landscapes. Biol. Conserv. 2005, 121, 479-494. [CrossRef]

14. Heimpel, G.E.; Jervis, M.A. Does floral nectar improve biological control by parasitoids? In Plant-Provided Food for Carnivorous Insects. A Protective Mutualism and Its Applications; Wäckers, F.L., van Rijn, P.C.J., Bruin, J., Eds.; Cambridge University Press: Cambridge, UK, 2005.

15. Tscharntke, T.; Bommarco, R.; Clough, Y.; Crist, T.O.; Kleijn, D.; Rand, T.A.; Tylianakis, J.M.; Nouhuys, S.V.; Vidal, S. Conservation biological control and enemy diversity on a landscape scale. Biol. Control 2007, 43, 294-309. [CrossRef]

16. Cullen, R.; Warner, K.D.; Jonsson, M.; Wratten, S.D. Economics and adoption of conservation biological control. Biol. Control 2008, 45, 272-280. [CrossRef]

17. Thomson, L.J.; McKenzie, J.; Sharley, D.J.; Nash, M.A.; Tsitsilas, A.; Hoffmann, A.A. Effect of woody vegetation at the landscape scale on the abundance of natural enemies in Australian vineyards. Biol. Control 2010, 54, 248-254. [CrossRef]

18. Wäckers, F.L.; van Rijn, P.C.J. Pick and mix: Selecting flowering plants to meet the requirements of target biological control insects. In Biodiversity and Insect Pests: Key Issues for Sustainable Management; Gurr, G.M., Wratten, S.D., Snyder, W., Read, D.M.Y., Eds.; Wiley Blackwell: Oxford, UK, 2012; pp. 139-165.

19. Nicholls, C.I.; Altieri, M.A. Plant biodiversity enhances bees and other insect pollinators in agroecosystems. A review. Agron. Sustain. Dev. 2014, 33, 257-274. [CrossRef]

20. Lu, Z.-X.; Zhu, P.-Y.; Gurr, G.M.; Zheng, X.-S.; Read, D.M.Y.; Heong, K.-L.; Yang, Y.-J.; Xu, H.-X. Mechanisms for flowering plants to benefit arthropod natural enemies of insect pests: Prospects for enhanced use in agriculture. Insect Sci. 2014, 21, 1-12. [CrossRef]

21. Campbell, A.J.; Wilby, A.; Sutton, P.; Wäckers, F.L. Do sown flower strips boost wild pollinators abundance and pollination services in a spring-flowering crop? A case study from UK cider apple orchards. Agric. Ecosyst. Environ. 2017, 239, 20-29. [CrossRef]

22. Carvell, C.; Meek, W.R.; Pywell, R.F.; Goulson, D.; Nowakowski, M. Comparing the efficacy of agri-environment schemes to enhance bumble bee abundance and diversity on arable field margins. J. Appl. Ecol. 2007, 44, 29-40. [CrossRef]

23. Landis, D.A.; Wratten, S.D.; Gurr, G.M. Habitat management to conserve natural enemies of arthropod pests in agriculture. Ann. Rev. Entomol. 2000, 45, 175-201. [CrossRef]

24. Straub, C.S.; Snyder, W.E. Species identity dominates the relationship between predator biodiversity and herbivore suppression. Ecology 2006, 87, 277-282. [CrossRef]

25. Moreno, C.R.; Lewins, S.A.; Barbosa, P. Influence of relative abundance and taxonomic identity on the effectiveness of generalist predators as biological control agents. Biol. Control 2010, 52, 96-103. [CrossRef]

26. Stephens, M.J.; France, C.M.; Wratten, S.D.; Frampton, C. Enchancing biological control of leafrollers (Lepidoptera: Tortricidae) by sowing buckwheat (Fagopyrum esculentum) in an orchard. Biocontrol Sci. Technol. 1998, 8, 547-558. [CrossRef]

27. Goulson, D.; Ollerton, J.; Sluman, C. Foraging strategies in the small skipper butterfly, Thymelicus flavus: When to switch? Anim. Behav. 1997, 53, 1009-1016. [CrossRef]

28. Goulson, D.; Wright, N.P. Flower constancy in the hoverflies Episyrphus balteatus (Degeer) and Syrphus ribesii (L.) (Syrphidae). Behav. Ecol. 1998, 9, 213-219. [CrossRef]

29. Gegear, R.J.; Laverty, T.M. Flower constancy in bumblebees: A test of the trait variability hypothesis. Anim. Behav. 2005, 69, 939-949. [CrossRef]

30. Michener, C.D. The Bees of the World, 2nd ed.; The Johns Hopkins University Press: Baltimore, MD, USA, 2007.

31. Olesen, J.M.; Bascompte, J.; Elberling, H.; Jordano, P. Temporal dynamics of a pollination network. Ecology 2008, 89, $1573-1582$. [CrossRef]

32. Petanidou, T.; Kallimanis, A.S.; Tzanopoulos, J.; Sgardelis, S.P.; Pantis, J.D. Long-term observation of a pollination network, fluctuation in species and interactions, relative invariance of network structure, and implications for estimates of specialization. Ecol. Lett. 2008, 11, 564-575. [CrossRef]

33. Kallimanis, A.S.; Petanidou, T.; Tzanopoulos, J.; Pantis, J.D.; Sgardelis, S.P. Do plant-pollinator interaction networks result from stochastic processes? Ecol. Model. 2009, 220, 684-693. [CrossRef]

34. Kunin, W.E. Sex and the single mustard: Population density and pollinator behaviour effects on seed-set. Ecology 1993, 74, 2145-2160. [CrossRef]

35. Petanidou, T.; DenNijs, J.C.M.; Oostermeijer, J.G.B. Pollination ecology and constraints on seeds of the rare perennial Gentiana cruciata L. in the Netherlands. Acta Botanica Neerlandica 1995, 44, 55-74. [CrossRef]

36. Shavit, O.; Amots, D.; Ne'eman, G. Competition between honeybess (Apis mellifera) and native solitary bees in the Mediterranean region of Israel-Implications for conservation. Isr. J. Plant Sci. 2009, 57, 171-183. [CrossRef]

37. Stanghellini, M.S.; Ambrose, J.T.; Schultheis, J.R. The effects of honey bee and bumble bee pollination on fruit set and abortion of cucumber and watermelon. Am. Bee J. 1997, 137, 386-391. 
38. Balzan, M.V.; Bocci, G.; Moonen, A.-C. Augmenting flower trait diversity in wildflower strips to optimise the conservation of arthropod functional groups for multiple agroecosystem services. J. Insect Conserv. 2014, 18, 713-772. [CrossRef]

39. Balzan, M. Flowering banker plants for the delivery of multiple agroecosystem services. Arthropod. Plant Interact. 2017, 11, 743-754. [CrossRef]

40. Aguilar-Fenollosa, E.; Pascual-Ruiz, S.; Hurtado, S.; Jacas, J.A. Efficacy and economics of ground cover management as a conservation biological control strategy against Tetranychus urticae in clementine mandarin orchards. Crop Prot. 2011, 30, 1328-1333. [CrossRef]

41. Paredes, D.; Cayuela, L.; Campos, M. Synergistic effects of ground cover and adjacent vegetation on natural enemies of olive insect pests. Agric. Ecosys. Environ. 2013, 173, 72-80. [CrossRef]

42. Karamaouna, F.; Kati, V.; Volakakis, N.; Varikou, K.; Garantonakis, N.; Economou, L.; Birouraki, A.; Markellou, E.; Liberopoulou, S.; Edwards, M. Ground cover management with mixtures of flowering plants to enhance insect pollinators and natural enemies of pests in olive groves. Agric. Ecosyst. Environ 2019, 274, 76-89. [CrossRef]

43. Jervis, M.A.; Kidd, N.A.C.; Fitton, M.G.; Huddleston, T.; Dawah, H.A. Flower-visiting by hymenopteran parasitoids. J. Nat. Hist. 1993, 27, 67-105. [CrossRef]

44. Bianchi, F.J.J.A.; Wäckers, F.L. Effects of flower attractiveness and nectar availability in field margins on biological control by parasitoids. Biol. Control 2008, 46, 400-408. [CrossRef]

45. Kremen, C.; Bugg, R.L.; Nicola, N.; Smith, S.A.; Thorp, R.W.; Williams, N.M. Native bees, native plants and crop pollination in California. Fremontia 2002, 30, 41-49.

46. Kremen, C.; Williams, N.M.; Thorp, R.W. Crop pollination from native bees at risk from agricultural intensification. Proc. Nat. Acad. Sci. USA 2002, 99, 16812-16816. [CrossRef]

47. Winfree, R.; Williams, N.M.; Gaines, H.; Ascher, J.S.; Kremen, C. Wild bee pollinators provide the majority of crop visitation across land-use gradients in New Jersey and Pennsylvania, USA. J. Appl. Ecol. 2007, 45, 793-802. [CrossRef]

48. Rader, R.; Howlett, B.G.; Cunningham, S.A.; Westcott, D.A.; Edwards, W. Spatial and temporal variation in pollinator effectiveness: Do unmanaged insects provide consistent pollination services to mass flowering crops? J. Appl. Ecol. 2012, 49, 126-134. [CrossRef]

49. Garantonakis, N.; Varikou, K.; Birouraki, A.; Edwards, M.; Kalliakaki, V.; Andrinopoulos, F. Comparing the pollination services of honey bees and wild bees in a watermelon field. Sci. Hortic. 2016, 204, 138-144. [CrossRef]

50. Delaplane, K.S.; Mayer, D.F. Crop Pollination by Bees; CABI Publishing: New York, NY, USA, 2000.

51. Winfree, R.; Kremen, C. Are ecosystem services stabilized by differences among species? A test using crop pollination. Proc. R. Soc. B 2009, 276, 229-237. [CrossRef]

52. Bartomeus, I.; Park, M.G.; Gibbs, J.; Danforth, B.N.; Lakson, A.N.; Winfree, R. Biodiversity ensures plant-pollinator phenological synchrony against climate change. Ecol. Lett. 2013, 16, 1331-1338. [CrossRef] 